\title{
INVESTIGATION OF KARST COLLAPSES USING INTEGRATED GEOPHYSICAL METHODS: AN EXAMPLE FROM CONGHUA DISTRICT, GUANGZHOU CITY, CHINA
}

\section{RAZISKOVANJE UDOROV NA KRAŠKIH OBMOČJIH Z UPORABO INTEGRIRANIH GEOFIZIKALNIH METOD: PRIMER IZ OKROŽJA CONGHUA, MESTA GUANGZHOU, KITAJSKA}

\author{
Chengliang DU ${ }^{1}$, Yongsheng $\mathrm{ZHOU}^{2}$, Fuping $\mathrm{GAN}^{3,{ }^{*}}$ \& Yinxiang $\mathrm{CHEN}^{3}$
}

\begin{abstract}
UDC 551.442:550.832(510-13)

Chengliang Du, Yongsheng Zhou, Fuping Gan \& Yinxiang Chen: Investigation of karst collapses using integrated geophysical methods: an example from Conghua district, Guangzhou city, China

Integrated geophysical methods were used to investigate the geological conditions of karst collapses in Aotou, Conghua District, Guangzhou City. Based on audio frequency magnetotelluric (AMT) soundings, high-density electric signals and microtremors, a series of features, including the soil structure and thickness, faults, and hidden karst, were detected from shallow to deep subsurface regions in three-dimensional (3-D) space. These were then compared with geologic and drilling data. The measurements of micro-vibrations and high-density electric signals revealed that the strata in the collapsed area consists of clay and medium-grain sand, which is approximately $8-15 \mathrm{~m}$ thick and arranged as a multiple-element structure. The AMT soundings uncovered a hidden structure in the subsurface, which lies at the core of a syncline and adjacent to a contact zone between soluble limestone and non-soluble granite. Combined with the geologic data, the survey using the high-density electric method also showed that the study area hosts the Shidengzi Formation from the Datang Stage of the lower Carboniferous, which contain carbonaceous micrite and dolomitic limestone, locally intercalated with thin quartz siltstone, with well-developed karst. Collectively, the soil structure,
\end{abstract}

Izvleček

UDK 551.442:550.832(510-13)

Chengliang Du, Yongsheng Zhou, Fuping Gan \& Yinxiang Chen: Raziskovanje udorov na kraških območjih z uporabo integriranih geofizikalnih metod: primer iz okrožja Conghua, mesta Guangzhou, Kitajska

Pri raziskovanju geoloških razmer za pojav udorov na območju krasa v Aotouju, okrožju Conghua, mesta Guangzhou so bile uporabljene integrirane geofizikalne metode. $\mathrm{Z}$ uporabo avdiofrekvenčnih magnetno teluričnih (AMT) sondiranj, visokofrekvenčnih električnih signalov in mikrotremorjev smo zaznali razne elemente $\mathrm{v}$ podzemlju, kot so debelina in struktura prsti, prelomi in nepoznani podzemni prostori. Izsledki so bili primerjani s podatki geoloških kartiranj in napravljenih vrtin. Meritve mikrovibracij in električnih signalov so razkrile, da so formacije na območju udorov sestavljene iz gline in srednje zrnatega peska, v skupni debelini približno 8-15 m. Magnetno telurično sondiranje je pod površjem razkrilo neznano strukturo, ki leži na jedru sinklinale ob stiku med topnim apnencem in netopnim granitom. Skupaj z geološkimi podatki je metoda $\mathrm{z}$ električnimi signali pokazala, da področje študije zajema formacijo Shidengzi, stopnje Datang iz spodnjega Karbona, ki vsebuje mikritni in dolomitni apnenec, ki se lokalno izmenjuje $s$ tankimi plastmi kremenovega meljevca. Na tem območju je nastal dobro razviti kras. Ugodna sestava prsti, neznane strukture pod površjem in zakrasevanje zagotavljajo dobre razmere za nastanek udorov. Glavni dejavniki udora kraških območij so

\footnotetext{
${ }^{1}$ Guilin University of Technology, Institute of Earth Sciences; No.12, Jiangan Road, Guilin, Guangxi, China; e-mail: chldu_123@163.com

${ }^{2}$ Guilin University of Technology, School of Business; No.12, Jiangan Road, Guilin, Guangxi, China; e-mail: 275127955@qq.com

${ }^{3}$ Institute of Karst Geology of Chinese Academy of Geology Sciences; No. 50, Qixing Road, Guilin, Guangxi, China, e-mails: ganfp555@163.com,13807737473@163.com

* Corresponding author
}

Received/Prejeto: 29.12 .2019

DOI: $10.3986 /$ ac.v49i2-3.7786 
hidden structure in the subsurface, and karst development provide the primary conditions for collapses. The main triggering factors for the karst collapses are seasonal variations in groundwater levels and excessive groundwater withdrawals. These results can provide guidance for the selection and application of geophysical methods for the examination of this issue in other areas with similar geology.

Key words: karst collapse, Chonghua of Guangzhou, 3-D joint geophysical survey. sezonska nihanja nivojev podzemne vode in čezmerna črpanja podtalnice. Pridobljeni izsledki zagotavljajo smernice za izbor in uporabo ustreznih geofizikalnih metod za raziskovanje teh težav v drugih regijah s podobno geologijo.

Ključne besede: udori na kraških območjih, okrožje Chonghua v mestu Guangzhou, 3-D geofizikalna raziskava.

\section{INTRODUCTION}

Within a range less of than $1 \mathrm{~km}^{2}$ of farmland in Bumei village, Aotou, Chonghua District, Guangzhou City, 47 sites of karst collapses have successively appeared over a short period of time. The collapses have damaged large areas of cultivated land and adversely affected the lives of local residents (Fig. 1).

The study area which is prone to karst collapses lies at the core of a regional syncline and is nearby a contact zone between soluble limestone and non-soluble granite, the study area hosts the Shidengzi Formation, Datang Stage, Lower Carboniferous, which contains carbonaceous micrite and dolomitic limestone, locally intercalated with thin quartz siltstone, with well developed karst, Collectively, the soil structure, hidden structure in the subsurface, and karst development have provided the primary conditions for collapses. The main triggering factors for karst collapses are the seasonal variations of groundwater levels and excessive groundwater withdrawals.

Based on the studies described above, we found the formation of the karst collapse has a specific relationship with a series of factors in this area. It has been clearly demonstrated that it is possible to solve the problem with only one $2-\mathrm{D}$ electrical sounding profile and one audio magnetotelluric (AMT) profile, together with a grid of microtremor measurements. Three techniques, i.e., micro-vibration, high-density electric signal, and audio frequency magnetotelluric (AMT) sounding methods, were selected to conduct this investigation as a joint survey.

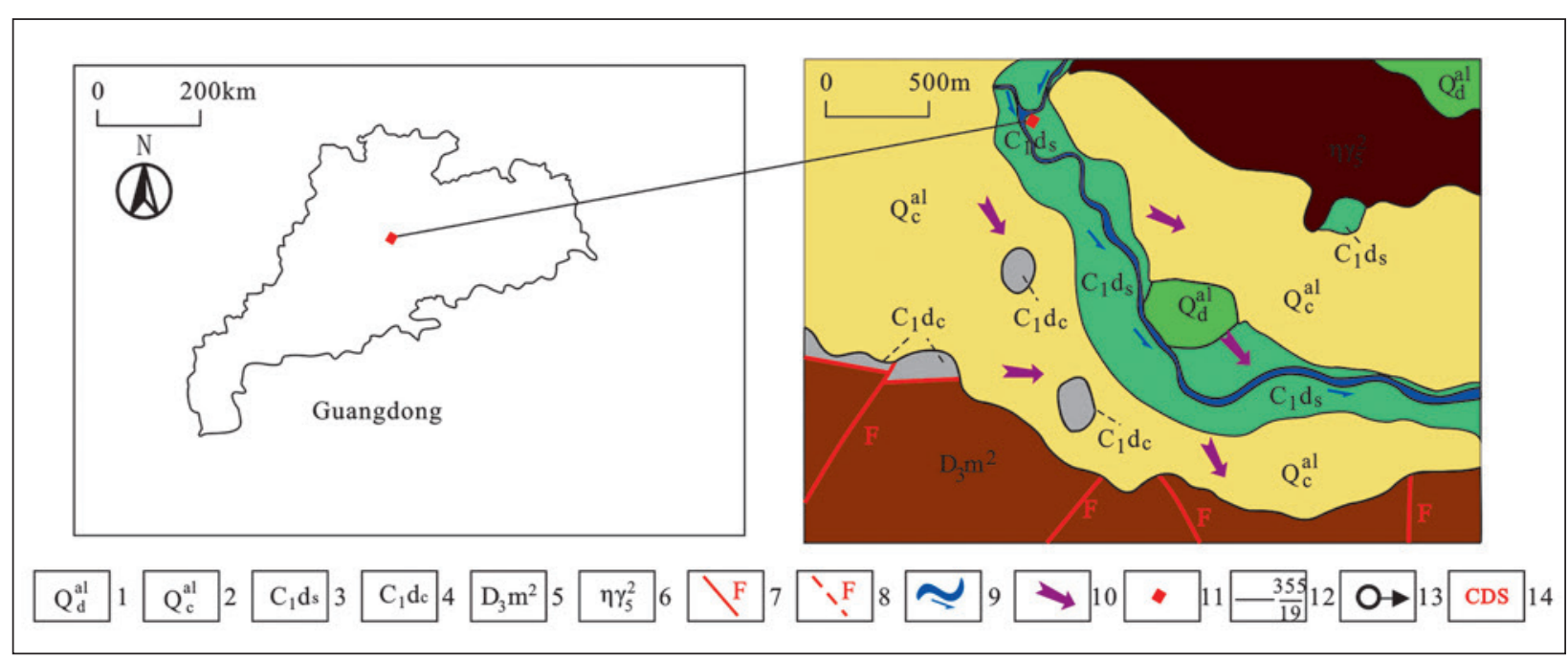

Fig. 1: Left: Location of the study area. Right: Geology of the study area.

1. Quaternary (first stage) fluvial deposit; 2. Late Quaternary (second stage) fluvial deposit; 3. Shidengzi Formation (Carboniferous); 4. Ceshui Formation (Carboniferous period); 5. Maozifeng Formation; 6. Adamellite; 7. Fault; 8. Inferred fault; 9. Surface runoff and flow direction; 10. Direction of groundwater; 11. Study area; 12. Survey lines (point/line); 13. Method for three-electrode electrical sounding; 14. Audio magnetotelluric sounding. 


\section{GEOLOGY OF THE STUDY AREA}

\section{GEOLOGIC STRUCTURE AND LITHOLOGY}

In terms of the tectonic setting, the study area lies at the southern segment of the Qingyuan-Anjiu fault zone and north of the Zengcheng uplift area in the Fugang-Fengliang sub-tectonic zone within the Nanling latitudinal tectonic system. Two structural systems striking E-W and NW-SE exist in the study area (Zhi et al. 2006). The Luochun-Shikeng syncline is the primary fold structure in the study area, whose core is composed of the Shidengzi Formation from the Datangjie Stage of the lower Carboniferous, with gravel-bearing carbonaceous micrite and well-developed karst. The Tangbei and Pujing faults lie north and south of the study area, respectively, striking nearly EW. The Xiaokeng fault trends from $290^{\circ}$ $310^{\circ}$ with nearly vertical plane that cuts through the lower Carboniferous and Yanshan diorite-granite from the second period. The Qigan and Xiaokeng faults have the most significant influence on the study area (Fig. 2).

\section{HYDROGEOLOGIC AND ENGINEERING GEOLOGY CONDITIONS}

Atmospheric precipitation and the tributaries of the Zhujiang River system are respectively the vertical and lateral water suppliers within the study area. Groundwater flows from the northwest to southeast where it forms a runoffdischarge region, with groundwater levels of 0.1-10.65 $\mathrm{m}$ and annual variations at amplitudes of 1.2-4.6 $\mathrm{m}$. The groundwater in the study area can be classified into pore water in the Quaternary beds, karst water in the carbonate rock, and crack water in the carbonate rock, where the latter two groundwater areas receive water from the first type of groundwater. The Earth engineering zone of the study area can be divided into the following two subzones: first-order flood land terraces and second-order terraces. Moreover, the rock mass engineering zone can be classified into the following three sub-zones: detrital rock, carbonate rock, and granite composites.

The study area is covered with the Quaternary strata, and the covering soil layer are mainly clay and medium sand, the thickness of covering soil is always form 10 to $15 \mathrm{~m}$. Clay is generally $1.5 \mathrm{~m}$ to $6.2 \mathrm{~m}$, medium sand is average $0.8 \mathrm{~m}$ to $5.2 \mathrm{~m}$. Two types of soil layers structure distribute in the study area, the first type is clay in the upper, medium sand in the middle and clay on the bottom, namely, clay - medium sand - clay; The second type is medium sand in the upper, clay in the middle and medium sand on the bottom, namely, medium sand clay - medium sand (Fig. 3).

The clay cover of the study area largely behaves as a hard plastic, with little deformation and good stability. The underlying medium-grain sand beds have a loose structure, easily deform via groundwater suffusion, and, thus, the beds show poor stability. When seasonal variations in groundwater levels occur or there are excessive groundwater withdrawals, karst water can suffuse to the overlying sand beds via karst mouths or windows in the bedrock surface, along with transported sand grains. This process leads to sand bed deformation. Consequently, near the interface between the plastic-like clay beds and sand beds, there is the progressive formation of cavities or potential holes. As the deformation of the overlying clay in these cavity beds reaches a critical state, karst collapses finally occur. Therefore, such an upper-hard and lowersoft Earth structure is typically prone to karst collapses.

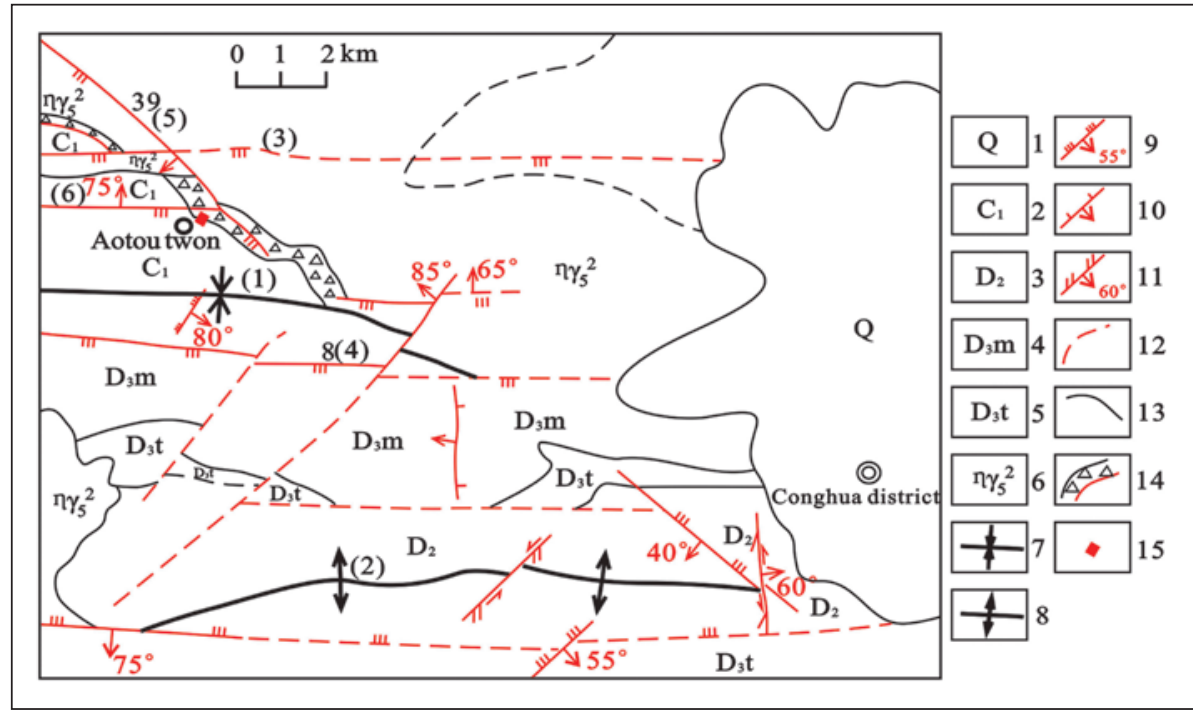

Fig. 2: Geology of the study area (according to the 1:5 million Conghua geological map sheet (F-49-24-A)).

1. Quaternary; 2. Lower Carboniferous; 3. Middle Devonian; 4. Maozifeng Formation; 5. Tianziling Formation; 6. Adamellite; 7. Syncline; 8. Anticline; 9. Compressive fault; 10. Extensional fault; 11. Shear fault; 12. Inferred fault; 13. Geologic boundary; 14. Contact zone; 15. Study area: (1) LuochunShikeng syncline; (2) Xinanli-Fenghuang anticline; (3) Tangbei fault; (4) Pujing fault; (5) Xiaokeng fault; (6) Qigan fault. 


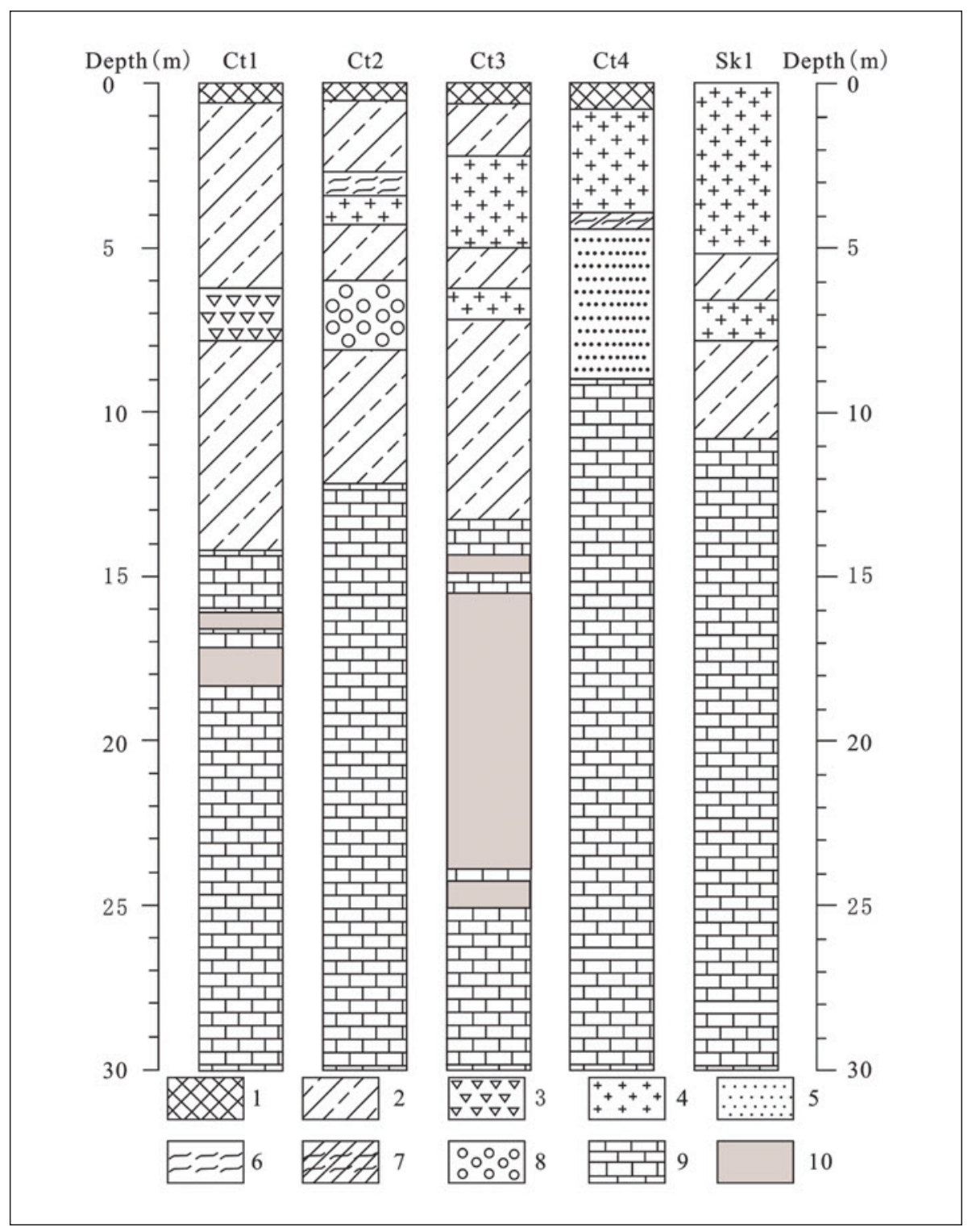

Fig. 3: Columnar diagrams of five boreholes in an area of karst collapse.

1. Cultivated soil; 2. Silty clay; 3. Coarse sand; 4. Medium sand; 5. Fine sand; 6. Muck; 7. Mucky soil; 8. Gravelly sand; 9. Limestone; 10. Karst cavity.

\section{SURVEY METHODS AND LAYOUT OF SURVEY LINES}

\section{SELECTION OF SURVEY METHODS}

In theory, numerous geophysical tools can be used to investigate areas of underground karst and karst collapses, such as apparent resistivity, geologic radar, microgravity, and shallow seismic exploration techniques, which are based on the differences in the physical properties between karst and surrounding rocks (Rousset et al. 1998; Giorgi et al. 2014; Li et al. 2015; Cueto et al. 2018). As the study area is situated in an economically developed region, electromagnetic interferences can affect geologic radar while artificial vibrations, such as from vehicles and machine operation, can influence the microgravity method. Therefore, both of these methods are not feasible for this area. The artificial source of shallow seismic exploration has the potential to induce new collapses in the karst area, such that this method is not feasible for this area either.

By receiving signals from the natural terrestrial electromagnetic field, the audio frequency magnetotelluric (AMT) sounding method measures the resistivity or conductivity of underground media. From a sounding site array, 2-D resistivity profiles can be produced to infer geologic bodies at depth (Kyu et al. 1998; Tinlin et al. 1998; Mcdonald et al. 2003), particularly faults, lithologic 
contact zones, and fractures belts characterised by relatively lower resistivity. Hence, this technique is suitable for probing deep structures.

The high-density electric technique is based on the electrical differences among underground media. Using an artificial electric field, this method permits one to infer the existence of geologic bodies in the subsurface by analysing currents conducted through rock or soil (Sjödahl et al. 2010; Huang et al. 2013; Mi et al. 2014). Clay beds, karst cracks, and water-bearing caves commonly have low electric resistivity while sand beds and intact limestone generally have high resistivity. Based on these differences, various inversion models, used in conjunction with this method, can provide colour images that reveal karst and karst collapses. Thus, this technique can be used to estimate the cover thickness and delineate the spatial distributions of Earth caves, karst collapses, soft earth bodies, and karst caves.

The microtremor method involves the use of natural low-frequency weak tremors that propagate in the Earth to interpret geologic structures throughout the subsurface. First, the strata characteristic frequencies at each site are measured. Data are then input into a fitting function to calculate the thickness of the cover above every site. Finally, maps of the cover thicknesses throughout the entire study area are constructed (Delgado et al. 2000; Gosar et al. 2010; Xu et al. 2013; Bignardi 2017; Liang et al. 2018).

In summary, these three methods were selected for the deployment of a three-dimensional (3-D) survey system to collect data from shallow to deep depths, as this was an optimal combination of geophysical methods to investigate the geologic conditions for karst and karst collapses in the study area.

\section{LAYOUT OF GEOPHYSICAL SURVEY LINES}

The survey lines were located at $30^{\circ}$ to the strike direction of the karst collapses in the study area. Overall, the

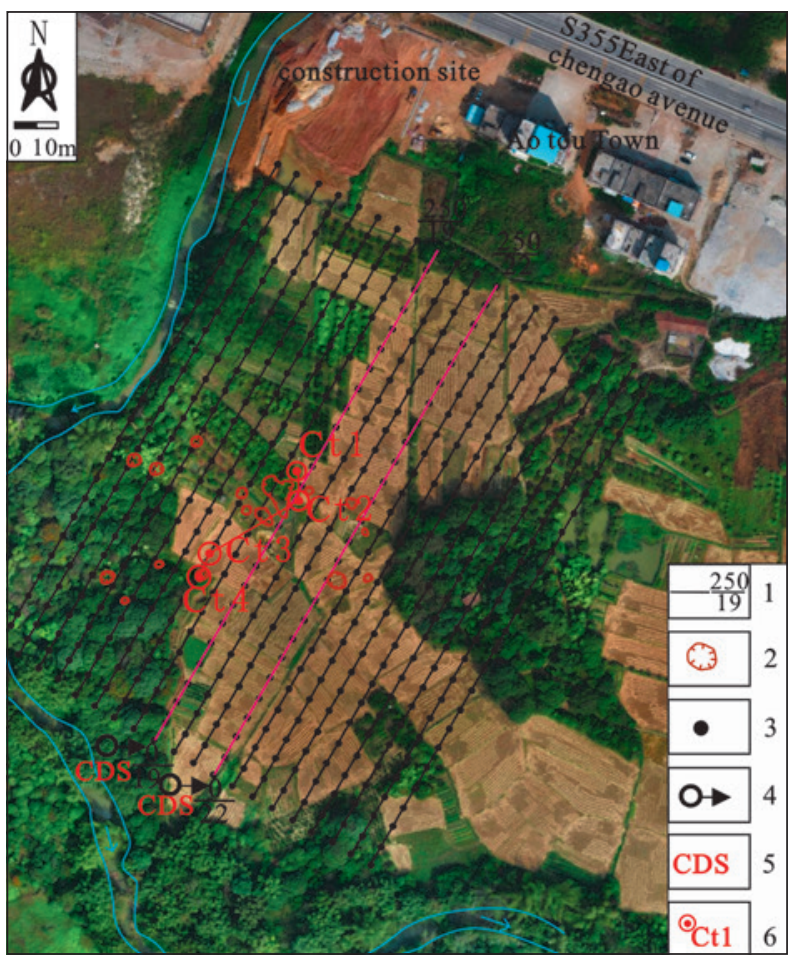

Fig. 4: Layout of the survey lines in a karst collapse typical area.

1. Survey lines (point/line); 2. Karst collapse; 3. Measurement point for the HVSR method; 4. Method for the three-electrode electrical sounding; 5. Audio magnetotelluric sounding; 6. Hydrogeology drilling.

survey lines were distributed in an approximately E-W direction, with a bead-like shape. In total, 30 survey lines were arranged in intervals of $10 \mathrm{~m}$, with lengths of $250 \mathrm{~m}$ each. Site intervals were set to $5 \mathrm{~m}$ for the microtremors and high-density electric surveys and $10 \mathrm{~m}$ for the AMT soundings. Microtremor measurements were conducted on all lines. The high-density three-electrode electric sounding was performed on line No. 19 and the AMT sounding was carried out on line No. 19 (Fig. 4).

\section{INVESTIGATION OF GEOLOGIC CONDITIONS FOR KARST COLLAPSES}

\section{PROBING HIDDEN STRUCTURES VIA THE AMT METHOD}

An AMT sounding was conducted along line No. 19 using a continuous conductivity instrument (EH4, jointly manufactured by EMI and the Geometrics Company, U.S.A.). The results show that a nearly vertical low-resistivity zone exists under the surface of the earth from $160 \mathrm{~m}$ to $200 \mathrm{~m}$, where values were less than $150 \Omega \cdot \mathrm{m}$. This zone has a large width and extends downward over $300 \mathrm{~m}$, presumably in association with a fault (Fig. 5). Comparisons indicate that this zone is in agreement with the known regional compressive fault (Fig. 2), whose footwall is dioritic granite, with poor water permeability, while its hanging wall is water-enriched limestone. Most karst collapses have occurred along this fault, indicating that it is a prominent structure that controls the karst hazards in the study area. 


\section{DETECTION OF HIDDEN KARST VIA THE HIGH- DENSITY ELECTRIC METHOD}

Hidden karst represents a migration channel and storage space for karst groundwater recharged by surface water, as well as a pathway for karst groundwater suffusion to overlying soil. This is a basic condition for karst collapses, whose presence determines the probability of collapse occurrence. More developed karst has a higher probability for a karst collapse. Thus, the clarification of hidden karst is critical for the prevention and control of karst collapses (Ma et al. 2015).

In the study area, inversion of the electric sounding data along line No. 19 showed a tongue-like low-resistivity $(20-50 \Omega \cdot \mathrm{m})$ zone at a depth of $\sim 30 \mathrm{~m}$ from the site 100 to $130 \mathrm{~m}$. A right oblique saddle-shaped lowresistivity $(50-150 \Omega \cdot \mathrm{m})$ zone was present at a depth of $20 \mathrm{~m}$ from the site 24 to $200 \mathrm{~m}$. We speculate that hidden karst cracks produced the former zone (Fig. 6) while the latter zone formed in accordance with a fault based on the geologic survey data (Fig. 2). Moreover, elliptical lowresistivity anomalies were found from the site 100 to 130 $\mathrm{m}$. Among these, the former zones have been verified by borehole Ct1 data adjacent to a karst collapse, where the residuals of the collapse occur at depths from $0.0-14.2$ $\mathrm{m}$ and three filled cavities at depths from 16.1-18.4 $\mathrm{m}$ were detected in the hole. Thus, we can infer that filled cavities also produced the elliptical low resistivity near site $100 \mathrm{~m}$.
As shown in Fig. 6, inversion of the high-density electric sounding data reflects the features of the shallow karst, which were consistent with the drilling data from borehole Ct1 along line No. 19 and the sounding results obtained by the AMT along line No. 19 (Fig. 5). We also note that the regional compressive fault controlled the hidden karst and karst collapses, as both are situated in the area southwest of this structure, where there are Carboniferous gravel-bearing micrite and dolomitic limestones, containing abundant karst water. Compare Fig. 5 with Fig. 6, the resolution in shallow karst, high density resistivity method is superior to AMT method. That is filling in the blind zone of detection shallow karst using AMT method. But the exploration depth is smaller by using three-electrode electrical sounding, that is its disadvantage.

\section{DETECTION OF SOIL HORIZON FEATURES VIA HIGH-DENSITY ELECTRIC METHOD AND MICROTREMORS}

Previous studies suggests that the maximum anomalies in the microtremor spectra correlate with the Quaternary cover in an approximately linear manner in the Zhujiang River delta region (Liang et al. 2018) (Fig. 7). This relation can be expressed as follows:

\section{$\mathrm{Z}=\mathrm{af}^{\mathrm{b}}$}

where $\mathrm{Z}$ is the thickness of the Quaternary cover,

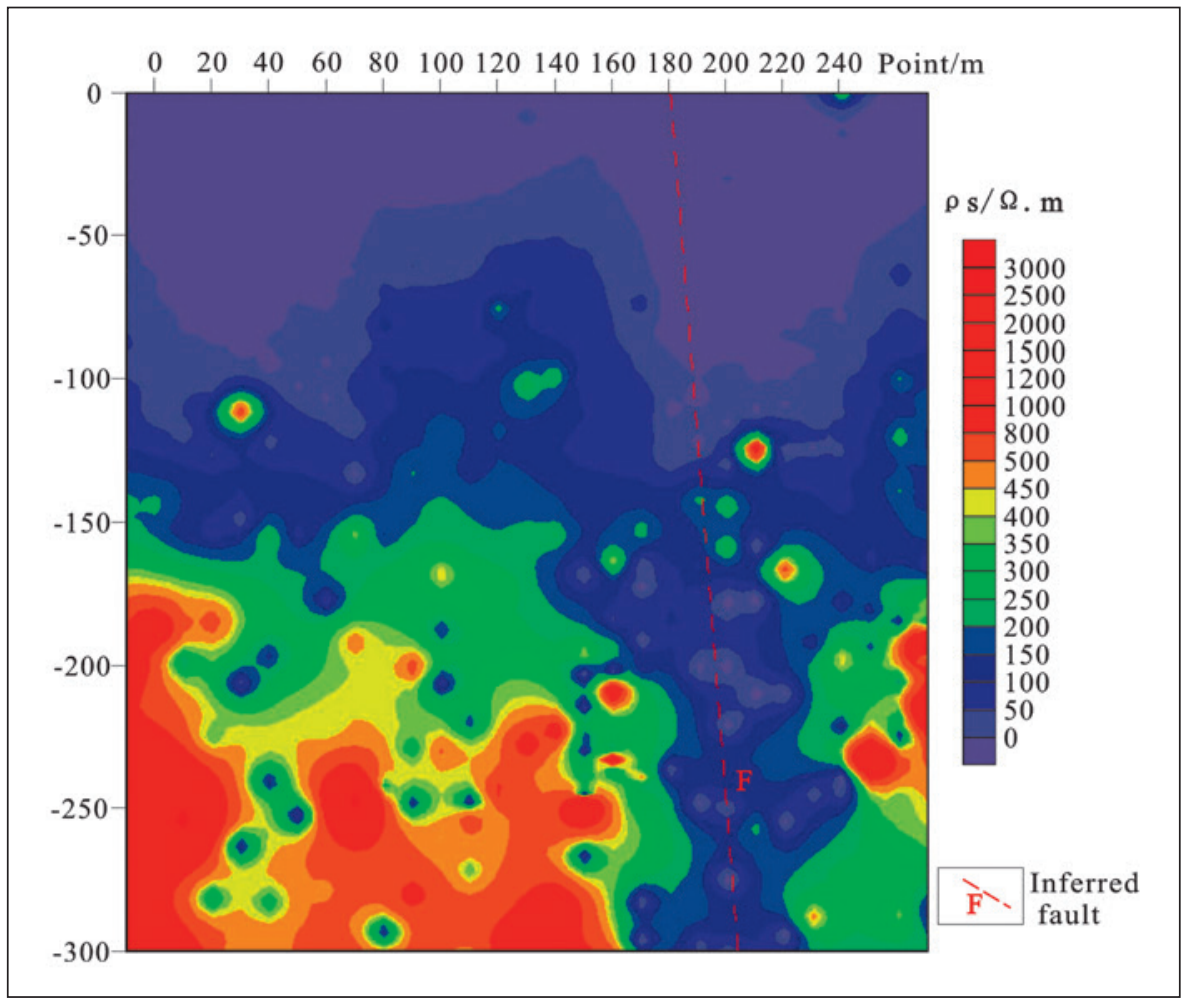

Fig. 5: Resistivity profiling with the CSAMT electric method at line 19. 
and $\mathrm{a}$ and $\mathrm{b}$ are fitting parameters that are dependent on the study area;

These parameters can be determined by statistical analyses of the microtremor spectra maxima and bedrock top depths from the electric sounding and drilling data (Fig. 8).

By using a TROMINO instrument, microtremor measurements were conducted over all 20 lines, with line spacings of $10 \mathrm{~m}$ and site intervals of $5 \mathrm{~m}$. Analyzing microtremor data acquired in study area, the peak frequency of HVSR for each measuring point was obtained. The sediments are both alluvial deposits and the underlying strata are limestone. The sediment thickness of each measuring point was calculated. The detected result is shown in Fig. 8. The interpreted sediment thickness in karst collapse area ranges from 8 to $27.6 \mathrm{~m}$. The north (a) Apparent resistivity curve of composite profile method

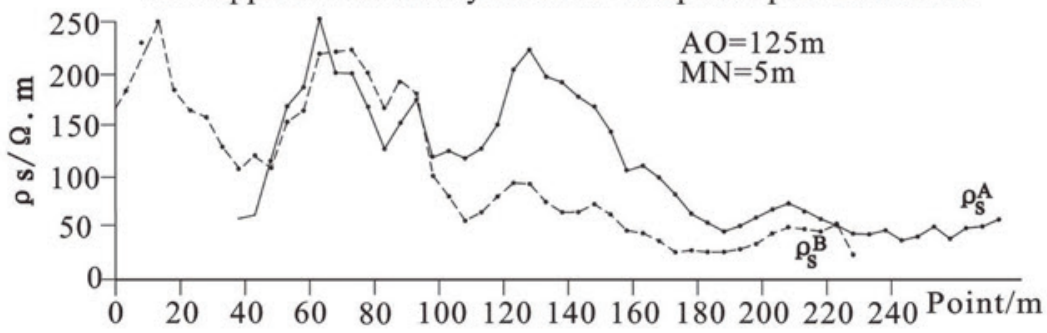

(b) Resistivity inversion of method of 3-electrode electrical sounding

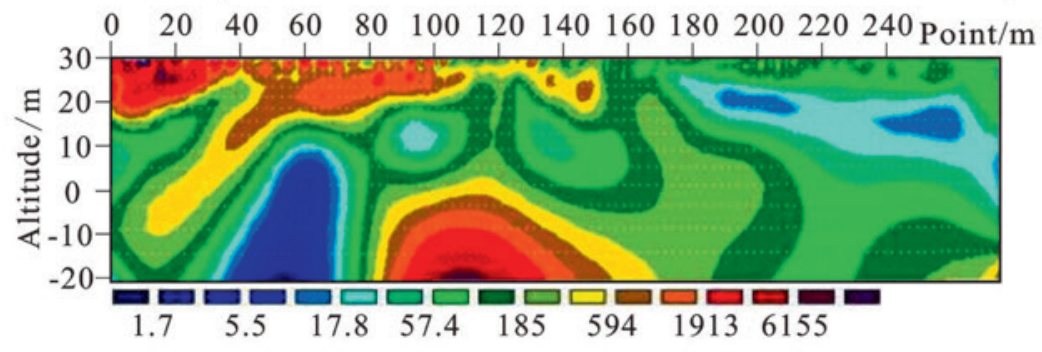

(c) Depth of inversion-Microtrenor spectum

HVSR

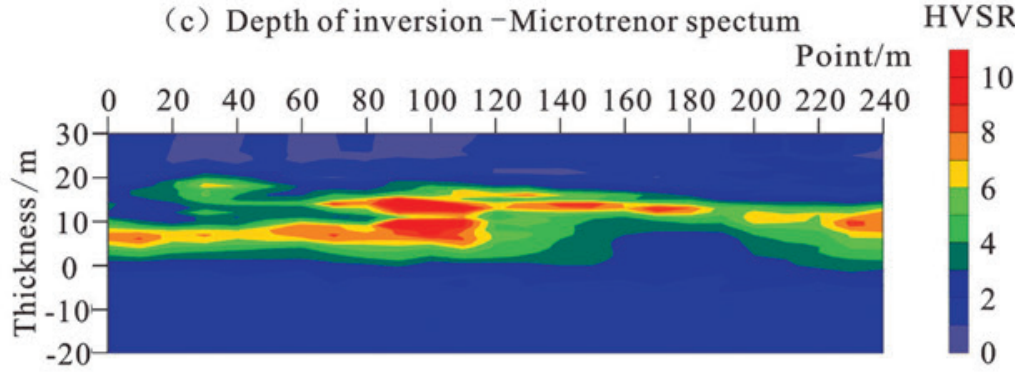

(d) Geological profile anomaly method of 3-electrode electrical sounding

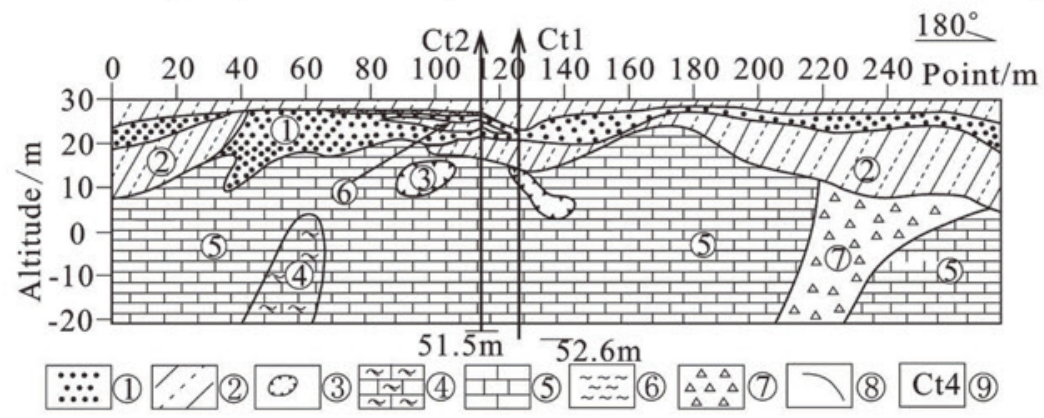

Fig. 6: Inferred profile from the high-density electric survey (along line No. 19) in a typical area of karst collapse in Conghua Lingnan village, Guangzhou. 1. Medium sand; 2. Silty clay; 3. Karst cave; 4. Dissolving limestone; 5. Limestone; 6. Silt; 7. Fracture zone; 8. Geological boundary; 9. Drill hole and serial numbers. 


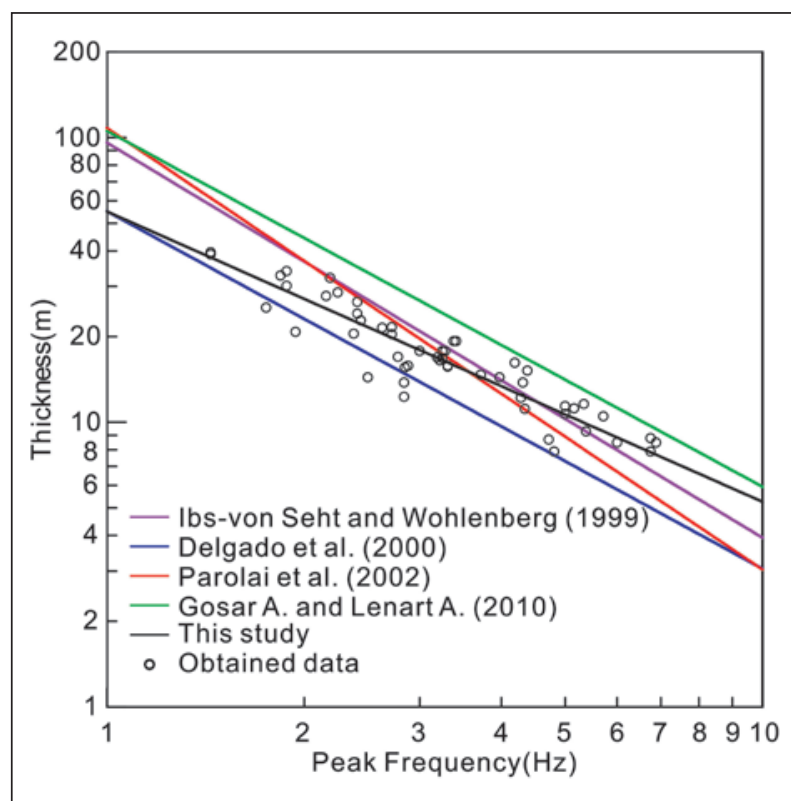

Fig. 7: Different fitting curves and the data obtained in the Pearl River Delta (Liang et al. 2018).

and south parts have relatively deep sediment thickness, while the west part is shallow. While five sinkholes are located in regions where the sediment thickness is between 16 and $24 \mathrm{~m}$. After the microtremor-detecting work, five boreholes numbered CT1, CT2, CT3, CT4 and SK1 were arranged. According to the drilling data, the sediments are composed of interbedded sand and silty clay, while some regions contain muck or mucky soil. The topsoil of CT1, CT2, CT3, CT4 is cultivated soil with a thickness of $0.5-0.8 \mathrm{~m}$. Sediment thickness, estimated sediment thickness according to microtremor data and the corresponding estimation error of the five boreholes. Estimated sediment thickness for CT2 has a relatively larger error of $4.1 \mathrm{~m}$, while for the other four boreholes, detecting errors are less than $2 \mathrm{~m}$.

Fig. 6 shows the contours of the soil horizon thickness and bedrock depth from this survey. The cover thickness is typically $7.9-24.8 \mathrm{~m}$ in the study area, which contains a multiple-element structure that likely consists of clay, medium-grained sand-clay, and medium-grained sand, as revealed by the drilling data (Fig. 3). The thickness of the soil horizon from the microtremor analysis was fairly consistent with that from the drilling analysis. The statistical analysis reported in Kang suggests that a multiple-layer soil structure with interbeds of clay and medium-grained sand is highly prone to karst collapses, where these layers are typically $10 \mathrm{~m}$ thick. The study area is characterrised by such conditions (Kang et al. 1990).

Drilling exploration revealed the soil structure in study area are multiple structure, namely, clay - medium sand - clay and medium sand - clay - medium sand. Microtremor measurements were conducted over all of the 20 lines with line spacings of $10 \mathrm{~m}$ and site intervals of $5 \mathrm{~m}$. Ratio spectrum of vertical_and horizontal component appeared bimodal maximum anomaly of vertical

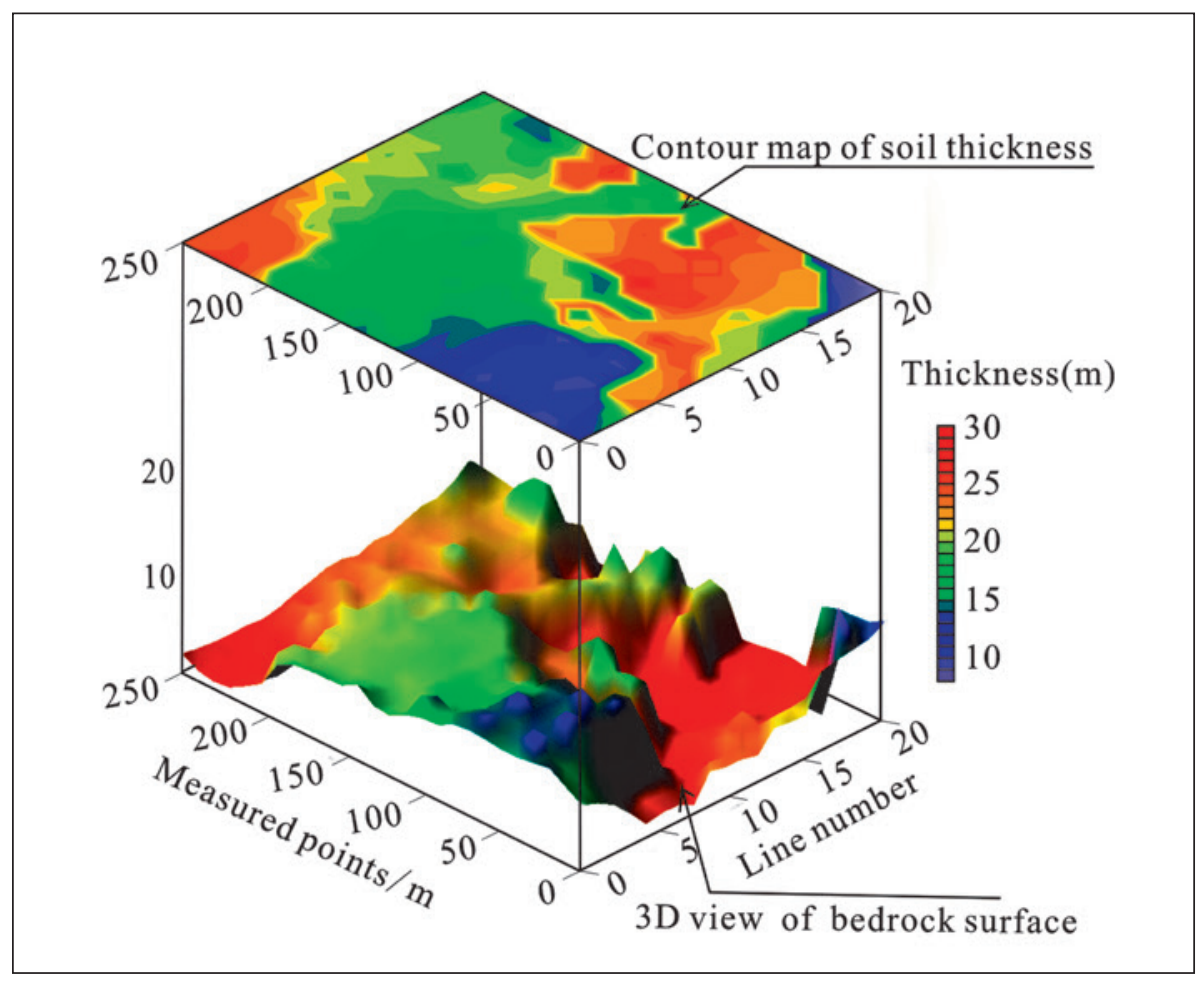

Fig. 8: 3-D view of the contours for the soil thickness and burial depths of the bedrock surface in the study area. 
superposition in point $100 \mathrm{~m}$ line No19 (Fig. 6), among them, the maximum abnormal of micro wave spectrum is in the deep of 2.6-3.4m, which has been verified by $\mathrm{Ct} 1$. Another maximum abnormal of micro wave spectrum in deep is consistent with the similar elliptical low resis- tance anomaly detected by high-density electric survey (Fig. 6), which is inference caused by filling-type karst cave. Combination of two different geophysical exploration methods, that will be effective in the effect advantages_and disadvantages complementation.

\section{DISCUSSION AND CONCLUSIONS}

In combination with drilling data, microtremor survey results revealed that the cover throughout the entire study area is a multiple-layer soil structure comprised of clays and medium-grained sands with thicknesses of $8.5-15 \mathrm{~m}$, which is prone to karst collapses. This is a shallow geologic condition for geologic hazards.

Based on geologic surveys, several area of strong karst in the subsurface were detected via the high-density electric method. Meanwhile, the study area hosts gravelbearing micrite and dolomitic limestone, locally intercalated with thin quartz silt rock. Such lithology is favourable for the development of karst.

The AMT soundings revealed hidden faults in the study area, which are consistent with data for the regional geology. This area lies at the junction of $\mathrm{E}-\mathrm{W}$-trending and NW-SE-striking tectonic systems. This area is also a contact zone for soluble limestone and non-soluble granite, providing the conditions to easily induce karst collapses.

In this example, using microtremor, high-density electric, and AMT methods to collect data from shallow to deep depths, we explored the thickness and structure of the soil horizon, karst strata, and presence of hidden faults, respectively, which allows us to clarify the geological conditions conducive to karst collapses in the study area. Our findings also demonstrate that such a combined 3-D geophysical survey is an effective approach to address karst collapse hazards.

The high-density electric method has a relatively high resolution for examining shallow karst while the AMT sounding method has a large probing depth for detecting hidden structures. Meanwhile, microtremors are useful for revealing the weak structure of the soil horizon. Each tool has its own advantages and limitations, such that the integration of these methods allows one to fully maximise the benefits of each tool. Besides, other geophysical methods can also be introduced into such an investigation. For example, geologic radar can be used to detect underground cavities and the shapes of karst collapses while the self-potential method can be used to monitor changes in groundwater levels.

Intensive groundwater activity is an important factor responsible for karst collapses in the study area (Chen et al. 2012; Xiao et al. 2018). As changes in the groundwater can lower the bearing capacity of rock and soil bodies and speed up the karst development process in a carbonate area, such activities can trigger karst collapses. Therefore, we must strengthen monitoring programs and provide reasonable exploitation guidance for the use of groundwater in the study area.

The applications of integrated geophysical methods to karst collapses in China and elsewhere globally have focused on the geological problems encountered during construction. The purpose of this study is to further examine the effectiveness of using combined geophysical techniques to investigate the geological conditions conducive to karst collapse occurrences.

\section{ACKNOWLEDGEMENTS}

This work was supported by the National Natural Science Foundation of China (41572232). We are grateful to Chen Yixiang, Gan Fuping at Institute of Karst Geol- ogy, Chinese Academy of Geosciences for his invaluable guide and help. We also thank the reviewers and editors for their efforts on this paper. 


\section{REFERENCES}

Bignardi, S., 2017: The uncertainty of estimating the thickness of soft sediments with the HVSR method: a computational point of view on weak lateral variations.- Journal of Applied Geophysics, 145, 28-38. https://doi.org/10.1016/j.jappgeo.2017.07.017

Cueto, M., Olona, J., Fernandez-Viejo, G., Pando, L. \& C. López-Fernández, 2018: Karst-induced sinkhole detection using an integrated geophysical survey: A case study along the Riyadh Metro Line 3 (Saudi Arabia).- Near Surface Geophysics, 16, 3, 70-281. https://doi.org/10.3997/1873-0604.2018003

Chen, Y.X. \& K. Pan, 2012: Application analysis of comprehensive geophysical exploration method in karst collapse detection.- Yangtze River, 43, 9-11.

Delgado, J., Casado, C.L., Estévez, A., Giner, J., Cuenca, A. \& S. Molina, 2000: Mapping soft soils in the Segura river valley (SE Spain): a case study of microtremors as an exploration tool.- Journal of Applied Geophysics, 45, 19-32.

Huang, W.S., Cai, S.J. \& W.X. Wang, 2013: Images of High Density Resistivity Method in Leakage Detecting of the Watertight Screen at Gushan Open-Pit Mine.Applied Mechanics and Materials, 341-342, $1167-$ 1170.

https://doi.org/10.4028/www.scientific.net/AMM.341342.1167

Gosar, A. \& A. Lenart, 2010: Mapping the thickness of sediments in the Ljubljana Moor basin (Slovenia) using microtremors.- Bulletin of Earthquake Engineering, 8, 501-518.

https://doi.org/10.1007/s10518-009-9115-8

Giorgi, L. \& G. Leucci, 2014: Detection of Hazardous Cavities Below a Road Using Combined Geophysical Methods.- Surveys in Geophysics, 35, 1003-1021.

Kyu, L.S., Ho, H.S., Young, L.D., Jinsoo, L., Soo, H.H. \& P.I. Hwa, 1998: Investigations of Faults using array CSAMT Method.- Geophysics \& Geophysical Exploration, 1, 2, 92-200.

Kang, Y.R., Xiang, S.J. \& J. Chen, 1990: Karst collapse in southern China.- Guangxi science and technology press, pp. 23-24, Guilin.

Liang, D., Gan, F., Zhang, W. \& L. Jia, 2018: The application of HVSR method in detecting sediment thickness in karst collapse area of Pearl River Delta, China.- Environmental Earth Sciences, 77, 259. https:// doi.org/10.1007/s12665-018-7439-x

Li, H.Z. \& X.J. Zhang, 2015: Comprehensive investigation and experimental study on several geophysical methods in karst subsidence area.- Journal of Southwest highway, 4, 117-121.
Mi, K.P., Park, S., Yi, M.J., Kim, C., Son, J.S., Kim, J.H. \& A.A. Adepelumi, 2014: Application of electrical resistivity tomography (ERT) technique to detect underground cavities in a karst area of South Korea.- Environmental Earth Sciences, 71, 2797-2806.

https://doi.org/10.1007/s12665-013-2658-7

Ma, D. \& H. Bai, 2015: Groundwater inflow prediction model of karst collapse pillar: a case study for mining-induced groundwater inrush risk.- Natural Hazards, 76, 1319-1334. https://doi.org/10.1007/ s11069-014-1551-3

Mcdonald, R. \& R. Davies, 2003: Integrated geophysical surveys applied to karstic studies.- Environmental \& Engineering Geoscience, 21, 32-35.

Sjödahl, P., Dahlin, T. \& S. Johansson, 2010: Using the resistivity method for leakage detection in a blind test at the Røssvatn embankment dam test facility in Norway.- Bulletin of Engineering Geology \& the Environment, 69, 643-658. https://doi.org/10.1007/ s10064-010-0314-y

Rousset, D., Genthon, P., Perroud, H. \& G. Sénéchal, 1998: Detection and characterization of near surface small karstic cavities using integrated geophysical surveys.- In: 4 th EEGS Meeting, $14^{\text {th }}-17^{\text {th }}$ September 1998, Barcelona. European Association of Geoscientists \& Engineers, cp-43-00097.

Tinlin, R.M., Hughes, L.J. \& A.R. Anzzolin, 1988: The Use of Controlled Source Audio Magnetotellurics (CSAMT) to Delineate Zones of Ground-Water Contamination-A Case History.- In: Collins, A. \& A. Johnson (eds.) Ground-water Contaminationl Field Methods. ASTM International, pp. 101-118, West Conshohocken.

Xu, P., Li, S., Du, J., Ling, S., Guo. H. \& B. Tian, 2013: Microtremor survey method: a new geophysical method for dividing strata and detecting the buried fault structures.- Acta Petrologica Sinica, 29, 5, 1841-1845. https://doi.org/10.2110/palo.2012.p12$129 \mathrm{r}$

Xiao, X., Xu, M., Ding, Q., Kang, X., Xia, Q. \& F. Du, 2018: Experimental study investigating deformation behavior in land overlying a karst cave caused by groundwater level changes.- Environmental Earth Sciences 77, 3, 64. https://doi.org/10.1007/s12665017-7102-y

Zhi B.F., He, J.M., Lu, Y.D., Chen, H.C., Liang, J.H. \& X.Y. Liang, 2006: New progress of 1.25 million environmental geological survey in Pearl River Delta Economic Zone.- Guangdong Geology, 22, 1, 28-37. 